\title{
JONATHAN EDWARDS AND HIS THEOLOGY OF REVIVAL
}

\author{
DINU MOGA*
}

Emanuel University of Oradea

\begin{abstract}
This part of our study has sought to establish that Edwards's theology of revival represents a discipline at the root of which lies the sovereign will of God, not the will of man. For Edwards, the engine of any true revival movement is the sovereign work of God and not the work of man and his endeavours to produce revival. Revival from the time of Edwards has been characterised by mysterious and supernatural aspects. The Spirit of God has been the operator of revival and the people of God are entirely dependent upon Him for revival. The theme of God's sovereignty becomes an important and essential theme for Edwards in the whole process of spiritual awakening.
\end{abstract}

KEYWORDS: Spirit of God, converted, sovereignty, awakening, glorification

\section{Introduction}

In this paper, we examine the core of Edwards's theology. For him a revival is a supernatural work, because it transcends man and comes from the Spirit of God. We explain how Edwards stressed the idea that the people of God are entirely dependent upon God for revival. When this truth is abandoned people run the risk of seeing themselves as the instruments that produce revival. When God's sovereignty is not acknowledged, instead of humbling themselves before God, men raise themselves above Him.

One of the most important elements in his theology is the doctrine of conversion. It is this doctrine that was attacked by the new changes that occurred later in the history of North America. At this point we aim to show that Edwards believed that human beings cannot be converted on their own, but when they are converted through the work of God's power, the transfiguration takes place within the whole of their personality.

* DINU MOGA (MTh in Historical Theology, Westminster Theological Seminary, 2005; $\mathrm{PhD}$ in Theology, Babeș-Bolyai University, 2015) teaches Systematic and Historical Theology at Emanuel University of Oradea. Email: mogadinu@gmail.com. 


\section{The Source of Revival: God's Sovereign Will}

From what we have said about the nature of revival, according to Edwards's description, it becomes clear that his theology of revival represents a discipline which underlines the mysterious and supernatural character of the revival. For him revival is a supernatural work, because it transcends man and comes from the Spirit of God. Such changes do not have their origin in man's effort but are the outcome of the Spirit's operation in the heart of man.

When the subject of God's sovereignty is under consideration, Edwards remembers that although initially 'it used to appear like a horrible doctrine' to him, the sovereignty of God became 'an exceeding pleasant, bright and sweet doctrine' (Edwards Works 16: 792). He holds that the sovereignty of God is his absolute independent right of disposition of all creatures according to his own pleasure. It has been argued that there are two reasons for the importance of stressing the value of Edwards as an exponent of this doctrine. First, prior to 1730, New England Calvinism had been modified by elements such as Stoddardeanism and Half-Way Covenant, and the preaching had abandoned to a considerable extent the citadel of sovereignty in the face of the siege of Arminianism. For these reasons, Edwards endeavoured to re-establish Calvinism. The second reason for the importance of God's sovereignty in Edwards's writings is its connection with the doctrine of atonement. Edwards exalts the sovereignty of God with respect to the atonement by giving a prominence to God as a Sovereign in applying and conducting as well as in originating the redemptive work. [For more details regarding these two reasons, see Rudisill (1971: 13-15).]

It is certainly true that Edwards approached revival in the same way. He stressed the idea that the people of God are entirely dependent upon God for revival, and God is sovereign in sending revival. Within the context of revivals there emerges a third reason for which God's sovereignty became an essential theological theme. During Edwards's time, revivals received ample attention from the media. This particularity has attracted significant attention from scholars and has been used to argue that the publicity given to revival played a central role in convincing believers on both sides of the Atlantic that an extraordinary Work of God was indeed under way when in fact everything had been man's invention (Lambert 1999: 14, 69-81, 102110). Edwards himself acknowledges that the spread of the news concerning the revivals helped considerably in the spread and propagation of the revivals themselves (Edwards Works 4: 120). But the great number of accounts on the revival could run the risk of temptation to a sense of personal merit and pride as well as creating a desire to attract more attention and to appeal for participation as a means of generating revival. Edwards realised this only too well in a letter written from Stockbridge to the Reverend 
Thomas Gillespie in Scotland. Jonathan Edwards looked back on the dangers involved in the historiography of the revivals, and makes this comment:

And there is this inconvenience attends the publishing of narratives of a work of God among a people: such is the corruption that is in the hearts of men, and even of good men, that there is great danger of making it an occasion of spiritual pride. There is great reason to think that Northampton people have provoked God greatly by trusting in their privileges and attainments, and the consequences may well be a warning to all God's people far and near, that hear of them. [See Edwards (Works 4: 563). This letter was written in July, 1751 as a reply to Gillespie's letter of February 2nd, of the same year. Thomas Gillespie (1708-1774) studied at the University of Edinburgh and at Philip Doddridge's Northampton Academy. Pastor at Carnock, Scotland, from 1741 to 1752, when he was deposed for refusing to help settle a minister resisted by the people, Gillespie founded the Relief Church of Scotland in 1761. For an analysis of Edwards's view on historiography, see Pfisterer (1975: 165-224).]

Edwards explains that man is virtually incapable of knowing and loving God without divine intervention in his life. There are two fundamental theological issues in the forefront of his discussions: firstly, God is sovereign in the work of revival and, secondly, man is incapable of knowing and loving God without the Trinitarian involvement in his life.

Such emphases are championed clearly in two of Edwards's sermons: in his first public sermon, delivered in Boston in July 1731 and entitled God Glorified in Man's Dependence, and in his second sermon, delivered in Northampton in 1733, entitled A Divine and Supernatural Light. [Both of these sermons are published in Edwards (Works 17: 196-216; 405-426).]

In God Glorified, Edwards maintains that God has absolute sovereignty in the redemption of mankind. Edwards was working in defence of the evangelical teaching that human beings are so fallen that they are utterly dependent on God for spiritual good, especially salvation. Working on the text from 1 Corinthians 1:29-31, Edwards proves that people depend on Christ for redemption, on God for Christ, and on the Holy Spirit for the faith that unites them. And then he concludes:

So that in this verse is shown our dependence on each person in the Trinity for all our good. We are dependent on Christ the Son of God, as he is our wisdom, righteousness, sanctification, and redemption. We are dependent on the Father, who has given us Christ, and made him to be these things to us. We are dependent on the Holy Ghost, for 'tis of him that we are in Christ Jesus; 'tis the Spirit of God that gives us faith in him, whereby we receive him, and close with him (Edwards Works 17: 201). 
Thus, in this Trinitarian exposition of 1 Corinthians 1:29-31, Edwards shows us how men have every aspect of their redemption from, in and through the three persons of the Trinity, deriving and developing the doctrine that God is glorified in the work of redemption in that there appears in it so absolute and universal a dependence on him. Therefore, we need to say, as the words of the biblical text suggests, "no flesh should glory in His presence'. We conclude, therefore, that when revival comes Edwards sees it as a God-chosen activity prompted by His good pleasure to reveal Himself, through the gospel, in a special way to sinful people.

\section{The Intent of Revival: the Glorification of God}

In all his works Edwards, being a true Calvinist, was concerned to stress that God must receive the glory as this belongs only to Him. Examining the same issue, Allan Story points to the fact that any true Calvinist must be concerned, before anything else, to make sure that God is glorified above all else, and that He is glorified in man's utter dependence upon Him and His free and sovereign grace (Story 1994: 77).

That is how Edwards approached revival. He saw it primarily as a Godglorifying exhibition of the sovereign grace of the God of the universe. In Some Thoughts, after he had at length determined to prove that revival is 'a wonderful work of God', not of the Devil, Edwards concludes that revival, the redemption of souls, is:

...in its nature and kind, the most glorious of any work of God whatsoever; and is always so spoken in Scripture. It is the work of redemption (the great end of all other works of God, and of which the work of creation was but a shadow) in the event, success and end of it: it is the work of new creation, that is infinitely more glorious than the old. I am bold to say, that the work of God in the conversion of souls, considered together with the source, foundation and purchase of it, and also the benefit, end and eternal issue of it, is a more glorious work of God than the creation of the whole material universe: it is the most glorious of God's works, as it above all others manifest the glory of God (Edwards Works 4: 344).

Edwards goes on to detail the various ways in which this work is a God-glorifying work. Firstly, he shows that revival is glorious in its nature and circumstances, a fact evident 'if we consider the unworthiness of the people that are the subject of it'. Secondly, the work of revival is very glorious if we consider the extent of it; 'being in this respect vastly beyond any former outpouring of the Spirit that ever was known in New England'. Thirdly, the work of revival is glorious through the great number of people who were turned from sin to God, 'and so delivered from a wretched captivity to sin and Satan, saved from everlasting burnings, and made heirs of eternal glory' (Edwards Works 4: 345). Fourthly, the work of revival is very 
glorious in its influences and effects on many that have been very ignorant and barbarous, as I before observed of the Indians and Negroes'. Fifthly, the work of revival is 'exceeding glorious in the high attainments of Christians, in the extraordinary degrees of light, love and spiritual joy, which God had bestowed upon great multitudes'.

There is always this endeavour and concern in Edwards's works to show in as detailed a way as possible the glorious and supernatural character of the awakening. In a repetitive way, he says:

The work has been very glorious and wonderful in many circumstances and events of it, that have been extraordinary, wherein God has in an uncommon manner made his hand visible, and his power conspicuous; as in the extraordinary degree of awakening, the suddenness of conversions in innumerable instances, in whom though the work was quick, yet the thing wrought is manifestly durable (Edwards Works 4: 346).

Such a display of the glory of God in the revival of souls receives its conclusive description from Edwards in the following way: 'If we consider these things, we shall be most stupidly ungrateful, if we don't acknowledge God's visiting of us as he has done, as an instance of the glorious triumph of free and sovereign grace' (Edwards Works 4: 345).

Story observes in similar manner: 'To Edwards, God is glorified in revival not only in that revival is glorious in its nature and extent, but especially in that God Himself is the source of it. The Church is entirely dependent upon God for revival, and God is absolutely sovereign over the sending of the revival. For this reason, all the glory for it belongs to Him' (Story 1994: 77-78).

\section{The Object of Revival: to Change Human Nature}

So far, the emphasis has been almost exclusively on the divine aspects of revival. God's sovereignty and glory in revival have been mentioned, but little has been said about the human being who becomes the object of God's plan to redeem and revive. In what follows we shall examine the way in which Edwards conceived those aspects of man's nature that are involved in revival.

From the onset, it must be said that Edwards's anthropology has also been thoroughly orthodox in a Calvinistic sense. He understands man as being dead in his sins and therefore he is either predestined to eternal life or to eternal death. Edwards sees man guilty before God and deserving condemnation, for he says: 'There are many scriptures which both declare the universal sinfulness of mankind, and also that all sin deserves and justly exposes to everlasting destruction, under the wrath and curse of God' (Edwards Works 3: 115). His depraved nature leads him away from God instead 
of bringing him to God; it makes him love evil more than good. Speaking about man's duty to love God, Edwards asserts that 'The sinful disrespect or unrespectfulness of his heart to God, is greater than his respect to him' (Edwards Works 3: 140). This depravity is so extensive as to leave man, though free to choose, yet unwilling to choose God, and unable because unwilling. Referring to the things which determine the will, Edwards asserts the following:

There is scarcely a plainer and more universal dictate of the sense and experience of mankind, than that, when men act voluntarily, and do what they please, then they do what suits them best, or what pleases them, but yet don't do what is agreeable to them, is the same thing as to say, they do what they please, but don't act their pleasure; and that is to say, that they do what they please, and yet don't do what they please (Edwards Works 1: 147-148).

It follows from this that man's will is captive to his nature, something that is true even of God, who is good by necessity of nature. 'He can't avoid being holy and good as he is', concedes Edwards. [Jonathan Edwards is working on a different way of understanding man's virtues and God's virtues, as seen in Edwards (1957: 277-280).]

This concerns man's faculties as well, and we must turn our attention at this point to the way in which Edwards understands man's constitution as a human being. In Religious Affections, Edwards clearly departed from the view which distinguishes in man three separate faculties: the will, the intellect and the emotions. Instead, he declares that the soul or mind has, from God, two faculties. The understanding, which is, 'that by which it is capable of perception and speculation, or by which it discerns and views and judges of things', and the inclination, which is 'that by which the soul does not merely perceive and view things, but is some way inclined with respect to the things it views or considers; either is inclined to 'em, or is disinclined, and averse from 'em; or is the faculty by which the soul does not behold things, as an indifferent unaffected spectator, but either as liking or disliking, pleased or displeased, approving or rejecting' (Edwards Works 2: 96). For Edwards, the will is not a separate faculty, but simply the inclination in its determining and governing the actions. Within the mind, the understanding and the inclinations, or affections, are closely tied. In dealing with the definition of affections, which could include such things as love and hate, desire and disgust, Edwards sought to place them at the centre of man's psychological makeup.

In conclusion, Edwards viewed man as having a mortal body and a soul that lives on after the death of the body. The seat of religion is in the soul, which in his case is identified with the mind. The mind is composed of the 
two faculties of understanding and inclination which mutually influence one another. Revival requires a work upon both the mind and the affections.

From God's point of view man's outcome is certain, but totally unknown to the man concerned. Though fallen, men are in full possession of their created faculties of thought and will. Their thought and will, however, are in the service of their 'heart' or their sinful disposition. As such sinners, they will understand the gospel of Christ if and when it reaches them and they will experience the Holy Spirit's stirring. But their hearts will be hostile to every divine overture and their minds will seek to justify their wicked hostility. Such is the man to whom the good news comes.

\section{The Sinner's First Step: Awakening}

Conviction, or humiliation, was considered by Edwards to be the sinners' first step to salvation. Another term used by Edwards for this first, but insufficient, step was 'awakening'. This term is asserted by Edwards in his personal narrative right from the outset: 'I had a variety of concerns and exercises about my soul from my childhood; but had two more remarkable seasons of awakening, before I met with that change, by which I was brought to those new dispositions, and that new sense of things, that I have since had' (Edwards Works 16: 790). Likewise, in his sermon on Jeremiah 2:23, where the work of the Spirit is explained, he says: 'he is for a time striving with them, awakening of them...' (Edwards Works 19: 265). Marsden observes rightly that 'awakening' became the most common term used for periodic outbreaks of religious enthusiasm in New England congregations (Marsden 2003: 26). With regard to its scope and results Edwards asserted:

This is one great design and end of God in suffering man to fall, that by a sense of evil he might have the greater sense of good. How congruous therefore is it, that God should prepare man by a sense of evil, which consists in sin and misery, for a sense of good; especially that good which consists in a salvation from those evils (Edwards Works 18, entry no 511: 55).

In Religious Affections Edwards explains that the heart is the proper locus of true religious experience. But the way to change the heart is by reaching the mind as the mind too must first be awakened to see how vile man's lusts are. There is an order for Edwards in the process of attaining conversion. Regarding the beginning of the process by which salvation may come to men, he asserts:

There must be a sense of guilt, of the evil nature of sin, and of the demerit of it, of the agreeableness and connection between that and the punishment; and there must also be a sense of Christ's redemption, that is, a belief of the truth and reality of it, and a sense of the nature of it. And here 'tis necessary that the 
sense of guilt should be first, which is first in fact, and is first in order of nature: and thus undoubtedly it ordinarily is first, in legal conviction; then [follows] gracious repentance, and then succeeds the explicit acting of faith on Jesus Christ. A sense of sin and guilt, being first in the order of nature, must of necessity be either before the other, or with it; it can't be after it (Edwards Works 18, entry no 528: 71).

This process is to be accomplished through the preaching of the Word. Until the Spirit of God begins to apply the Word to the minds and hearts of men, we do not have the beginning of the sinner's experience that may lead to actual salvation. Once the Word is preached to man and the Spirit does work in him, a response on his part is inevitable, and the first useful one is a conviction of the truth of the things preached.

According to Edwards a conviction seems to be a deeper and more durable realization that certain doctrines, especially the doctrine of a divine judgement, are true. Convictions are human reactions to the working of the divine Spirit, who 'doth the finishing strokes' on Christ's salvation. 'The work of the Holy Spirit as Christ's messenger is to convince men of sin, of righteousness and of judgement.'

The important question raised by Edwards in his sermon on Hosea 5:15 is how a sinner may be made sensible of God's wrath. He answers by saying that although men have lost 'a principle of love to God and all spiritual principles by the fall, yet natural conscience remains'. [From the sermon preached from Jeremiah 2:23: 'Conviction and the Uses of Order', see Edwards (Works 19: 261-271). These quotes are also presented in Gerstner (1991-1993, volume 3: 21-22) quoted by him as 'Unpublished MS sermon on Jer. 2:23, 'Persons ought to endeavour to be convinced of sin', Jan 173435 and Acts 7:51, 'Tis a great sin to resist the Spirit of God', April 1735, and 'unpublished MS sermon on John 16:8, 'That work of the Holy Ghost as Christ's messenger is to convince men of sin, of righteousness and of judgement', Spring-Summer, 1729.]

They still have a natural conscience. Conscience tells him that retribution must follow wrongdoings. Thus, the Spirit of God sets in to assist the work of conscience. The discussion with respect to the relationship between natural conscience and the Spirit of God in the work of convicting sinners becomes even clearer in the Divine and Supernatural Light. [Sermon on Matt. 16:17; 'A Divine and Supernatural Light, Immediately Imparted to the Soul by the Spirit of God, shown to be Both a Scriptural and Rational Doctrine', in Edwards (Works 17: 408-426).]

So, we see that this work of convicting is basically a natural work. It is the effect of the conscience of man merely amplified by the work of the Holy Spirit. It is a work of the Spirit on the unchanged nature of fallen man; it is 
not a change within the man. It differs in degree, but not in kind from the unaided work of conscience.

While Edwards makes this the beginning of the process that may lead to salvation, it is apparent that this, in itself, is not a saving activity. Men are not able to be saved without this work, but they could have this work of the Spirit all their lives without ever being saved.

All this does not imply that men are merely acted upon and not acting. 'Persons ought to endeavour to be convinced of sin' is the doctrine of the sermon on Jeremiah 2:23 (Edwards Works 19: 264). When convictions come, they must be carefully preserved. Edwards would argue that resisting the Spirit or quenching these convictions is dangerous. When the Word of God is preached-especially its solemn warnings—convictions come, awakening results. True acceptance of these convictions leads to conversion, usually at the end of a long and arduous path of seeking.

\section{The Transformation Brought by Revival: Conversion}

By the time Edwards became pastor in Northampton, the general ecclesiological climate had undergone an extensive change. Conversion theology became the dominating feature of every itinerant preacher, who had been much more inclined to ignore his pulpit in order to preach in the open air. Multitudes went to hear them because of their style, their readily understood theology, and 'the show'. In his helpful essay, C. C. Goen explains that revivalists knew how to use an arsenal of techniques which would have included the ability to frame their message in readily accessible phrases, the use of graphic and arresting illustrations of the terrors of hell and the joys of heaven, the control over the flow of their sermons with emotional appeals at the right psychological moment, and all these mastered with exceptionally stentorian voices with which to express the robustness of the message but the ultimate purpose of the entire undertaking was conversion (Edwards Works 4: 2-4).

Against this background, Edwards too preached relentlessly about conversion. Marsden points to the fact that the emphasis on this second stage is clearly noticeable also in the preaching of Edwards's father, Timothy. Prior to conversion potential converts not only had to recognize their guilt which deserved eternal flames but be 'truly humbled' by a total sense of their unworthiness (Marsden 2003: 28). In A Faithful Narrative, Edwards asserts, 'Conversion is a great and glorious work of God's power, at once changing the heart and infusing life into the dead soul' (Edwards Works 4: 177). Edwards understood conversion as the personal experience of strong feelings of guilt before God, godly sorrow for sin in abject repentance, release from the bondage of $\sin$, followed by a testimony to the fact of the new experience, often with ecstatic signs (Edwards Works 10: 506, 308). Conversion had 
inscrutable dimensions but also many visible ones. It brought about changes in the dispositions and aspirations of the converted. They exuded a sweetness of spirit, became involved in bringing praises to God, and often had a salutary effect on others. Conversions had a major impact on the life of the church as a whole. They caused an increase in church attendance and greater participation in the activities of the church.

Edwards noted also a change in the whole social climate of Northampton, particularly among the young adults of the town:

Although people did not ordinarily neglect their worldly business; yet there then was the reverse of what commonly is: religion was with all sorts the great concern, and the world was a thing only by and bye. The only thing in their view was to get the kingdom of heaven and everyone appeared pressing into it (Edwards Works 4: 150).

Edwards insists on the supernatural nature of the change involved in conversion. He wrote: 'And natural men are represented in Scripture as having no spiritual light, no spiritual life, and no spiritual being; and therefore, conversion is often compared to opening the eyes of the blind, raising the dead and a work of creation... and becoming new born children' (Edwards Works 2: 204). Noticeable from the first definition is that the change takes place at this stage. The locus where the change takes place is the heart of man, or the whole of his personality, and the result is new life. This life is, according to Edwards, 'infused' through the work of God's power. [A detailed and comparative analysis of the use of 'infusion' by Edwards with reference to conversion is presented by (Morimoto 2008: 13-36). Morimoto traces the origin of this vocabulary to a few factors such as the influence that Ames's Marrow of Theology exercised over New England theological education in general.]

This infusion is indispensable as men are spiritually, prior to regeneration, as dead as Lazarus in the tomb. Through many others of Edwards's reflections, it is clarified even further that the power of God's work and grace is the Holy Spirit. The effect of this infusion is by no means confined to the understanding or the will alone. It brings forth the knowledge of divine beauty and glory.

In what ways does the work of conversion affect the convert? Fundamental to Edwards's thoughts on conversion is that the infusion of grace causes a radical and abiding change in the disposition of the person. He asserts the following: 'We learn that the prime alteration that is made in conversion, that which is first and foundation of all, is the alteration of the temper and disposition and spirit of the mind' (Edwards Works 13: 462).

In conclusion, it is self-evident to Edwards that human beings cannot be converted on their own, because human beings have no natural capacity for 
religion. They are naturally blind to the things of religion, and 'without understanding' (Edwards Works 19: 519). If ever they are turned from sin, for Edwards God must be the cause of their conversion. Infused grace operates on this utterly helpless disposition of the unconverted. This grace, we say again, is nothing else but the Holy Spirit himself opening the eyes of the mind and enabling the person to see divine beauty and excellency. No human effort can cause this perception of divine beauty and excellency, since there is no disposition in their heart. Unconverted persons may hear the words of the Gospel, but since they do not have the right disposition, they 'can do nothing towards causing the knowledge of the things of the gospel... for the disposition, as we have shown, must necessarily be changed first' (Edwards Works 13, Entry no 123: 287). What is important to see from all this is that conversion consists of a change in disposition, which enables one to see the beauty of divinity. And when the work is performed, the change is fundamental. About the result of this change, we shall say more in what follows.

\section{The Effect of Revival: Perseverance of the Believer to the End}

When God calls men to salvation, that call comes to them in their capacity as rational and moral beings. In Edwards's theology God's call to man is universal and without exception in the sense that God commands everyone who hears the gospel to come to Christ. The command is to repent, believe and be saved. According to Edwards seeking for salvation should be done now, immediately, whatever may be the circumstances. Anyone who repents and believes will be saved. None will be rejected ever. No matter what a person has ever thought or done, if he comes to Christ in faith he will not be cast out. These statements are most relevant from a revival point of view.

The person transformed this way through the power of God's Spirit is a dramatically different person from the unconverted man. Our interest at this moment is to witness, briefly, Edwards's description of the converted Christian. The most beautiful description of a converted Christian I have encountered so far is the one made by Edwards in his Personal Narrative. He says:

The soul of a true Christian, as I then wrote my meditations, appeared like such a little white flower, as we see in the spring of the year; low and humble on the ground, opening its bosom, to receive the pleasant beams of the sun's glory; rejoicing as it were, in a calm rapture; diffusing around a sweet fragrancy; standing peacefully and lovingly, in the midst of other flowers round about; all in like manner opening their bosoms, to drink in the light of the sun (Edwards Works 16: 796). 
From this description, it follows that the converted Christian is basically a man connected to heaven as the source of his spiritual life. He has been supernaturally changed. His spiritual blindness has been removed. He still has the same faculties as the non-regenerate, but he has a new spiritual sense of the heart. His new disposition is for the things of God.

For Edwards, Christian living is part of the Spirit's work in the believer's life, as was conversion. The Spirit works to sanctify the believer. This is a gradual process and represents a continuation of the work that has already begun in the regenerate persons. In his History of Redemption Edwards mentions the sanctifying work of the Spirit within the context of other important steps in the ordo salutis.

And as God carries on the work of converting the souls of fallen men through all these ages, so he goes on to justify them, to blot out all their sins and to accept them as righteous in his sight through the righteousness of Christ, and to adopt them and receive them from being the children of Satan to be his own children. So he also goes on to sanctify, or to carry on the work of his grace which he has begun in them, and to comfort them with the consolation of his spirit and to glorify them, to bestow upon them when their bodies die that eternal glory which is the fruit of the purchase of Christ (Edwards Works 9: 121).

One of Edwards's emphases, noticeable in Religious Affections, is that 'gracious affections have their exercise and fruit in Christian practice'. For Edwards the true cause of Christian living, or the rise of 'gracious affections' in man's life, is the indwelling work of the Holy Spirit. The following quotation particularly captures the fundamental thesis of the man whose life has been restored to fellowship with God. After establishing that gracious affections exercise themselves in Christian practice, Edwards explains the way these affections are produced:

...gracious affections do arise from those operations and influences which are spiritual, and that the inward principle from whence they flow, is something divine, a communication of God, a participation of the divine nature, Christ living in the heart, the Holy Spirit dwelling there, in union with the faculties of the soul, as an internal vital principle, exerting his own proper nature, in the exercise of those faculties (Edwards Works 2: 392).

Christian practice becomes an important topic for Edwards, as this is the most important of all twelve signs by which one can judge the sincerity of godliness (Edwards Works 2: 406-407). In his work on the theology of Jonathan Edwards Conrad Cherry explains how Edwards continually reminds himself that faith is not only 'an exercise of the understanding' but also 'a falling in of the inclination, the choice, the affection' (Cherry 1966: 14). For Edwards it is vitally important to understand that religious faith is insepara- 
ble from one's active, practical life in the world, because to know the truth which God reveals to us through faith means to live by it. Edwards shows that there is a correspondence between the state of a man's heart and his outward behaviour. His whole objective is to prove that a man's actions must be the proper evidence of the state of the heart. The understanding and the will must be outworked in the attitude of the whole person. This is what Edwards called Christian practice: it was the most important fruit of true conversion.

This Christian living must be understood, therefore, as the effect of the Spirit's operation in man's life, but at the same time it is not an operation totally alien to the human subject, for it is only with human participation that this work is carried out. It may be likened to a tree yielding fruit. The fruit is, in one sense, totally the product of the tree, and yet what becomes manifest in the fruit is not from the tree itself but from the soil, the air, and the sunlight, without which it cannot exercise its disposition to bear fruit. Or, it is likened to the 'little white flower' cleansed by the blood of Christ, which, opening its bosom to receive the pleasant beams of the sun's glory spreads around the sweet smell of His spiritual perfume.

Edwards claimed Christian practice as the chief means through which one may be assured that he is a man of faith. Developing the same theme Cherry explains that practice, the performance of good works, exhibits the nature of faith before both man and God (Cherry 1966: 143-144).

In Christian practice, the saints are united closer and closer with God, and in this union, they become ontologically more and more conformed to the image of God. They participate in God's own holiness.

\section{Concluding Remarks}

This part of our study has sought to establish that Edwards's theology of revival represents a discipline at the root of which lies the sovereign will of God, not the will of man. For Edwards, the engine of any true revival movement is the sovereign work of God and not the work of man and his endeavours to produce revival. Revival from the time of Edwards has been characterised by mysterious and supernatural aspects. The Spirit of God has been the operator of revival and the people of God are entirely dependent upon Him for revival. The theme of God's sovereignty becomes an important and essential theme for Edwards in the whole process of spiritual awakening. Against any other contention mentioned so far, the underlying thought in Edwards's theology of revival is that when revival comes, it is a God-chosen activity, not a man-chosen enterprise, prompted by God's good pleasure to reveal Himself, through the gospel, in a special way to sinful people. The result of such a work is God's glorification, a preoccupation illustrated in detail in all of Edwards's works. 
A further important element in Edwards's theology of revival is the thought that man is constituted from a mortal body and a soul which lives after the death of the body. The gospel's message comes to man in his fallen state and man understands the call to repent as the Holy Spirit works in his heart. Under the influence of the preaching of God's Word, the Spirit of God begins to apply the Word to the mind and heart of man which eventually leads to an inevitable response on his part. This is the stage which Edwards calls conversion: it is axiomatic to him to show that conversion is a process which causes a radical and abiding change in the disposition of the person. Thus, it becomes evident that human beings cannot convert of their own volition as they have no natural capacity for religion. But once the conversion is achieved through the power of God's Spirit which becomes effective in man's life, the person so affected becomes a dramatically different person from the unconverted man. The converted person becomes linked with heaven for his spiritual life. In his new spiritual life, the believer is united more and more closely to God and participates in God's own holiness.

\section{Bibliography}

Edwards J (1957) Freedom of the Will. In Ramsey P (ed) The Works of Jonathan Edwards, volume 1. New Haven, CT: Yale University Press.

Edwards J (1970) Original Sin. In Holbrook CA (ed) The Works of Jonathan Edwards, volume 3. New Haven, CT: Yale University Press.

Edwards J (1972) Some Thoughts Concerning the Revival. In The Great Awakening. In Goen CC (ed) The Works of Jonathan Edwards, volume 4. New Haven, CT: Yale University Press.

Edwards J (1959) Religious Affections. In Smith JE (ed) The Works of Jonathan Edwards, volume 2. New Haven, CT: Yale University Press.

Edwards J (1972) The Distinguishing Marks. In The Great Awakening. In Goen CC (ed) The Works of Jonathan Edwards, volume 4. New Haven, CT: Yale University Press.

Edwards J (1972) Unpublished Letter of May 30, 1735. In The Great Awakening. In Goen CG (ed) The Works of Jonathan Edwards, volume 4. New Haven, CT: Yale University Press.

Edwards J (1972) A Faithful Narrative of the Surprising Work of God in the Conversion of Many Hundred Souls in Northampton and the Neighbouring Towns and Villages In The Great Awakening. In Goen CC (ed) The Works of Jonathan Edwards, volume 4. New Haven, CT: Yale University Press. 
Edwards J (1989) A History of the Work of Redemption. In Wilson JF (ed) The Works of Jonathan Edwards, volume 9 (New Haven, CT: Yale University Press.

Edwards J (1994) The Miscellanies, a-500. In Schafer TA (ed) The Works of Jonathan Edwards, volume 13. New Haven, CT: Yale University Press.

Edwards J (1999) Sermons and Discourses, 1730-173. In Valery MR (ed) The Works of Jonathan Edwards, volume 17. New Haven, CT: Yale University Press.

Edwards J (2000) The Miscellanies, Entry nos. 501-832. In Chamberlain A (ed) The Works of Jonathan Edwards, volumes 18. New Haven, CT: Yale University Press.

Edwards J (1957) Freedom of the Will. In Ramsey P (ed) The Works of Jonathan Edwards, volume 1. New Haven, CT: Yale University Press.

Edwards J (1970) Original Sin. In Holbrook CA (ed) The Works of Jonathan Edwards, volume 3. New Haven, CT: Yale University Press.

Edwards J (2001) Sermons and Discourses 1734-1738. In Lesser MX (ed) The Works of Jonathan Edwards, volume 19. New Haven, CT: Yale University Press.

Edwards J (1977) Apocalyptic Writings. In Stein SJ (ed) The Works of Jonathan Edwards, volume 5. New Haven and London: Yale University Press.

Edwards J (1980) Scientific and Philosophical Writings. In Anderson WE (ed) The Works of Jonathan Edwards, volume 6. New Haven, CT: Yale University Press.

Edwards J (2003) Sermons and Discourses, 1739-1742. In Stout HS and Hatch NO with Farley KP (eds) The Works of Jonathan Edwards, volume 22. New Haven and London: Yale University Press.

Edwards J (1998) Letters and Personal Writings. In Claghorn GS (eds) The Works of Jonathan Edwards, volume 16. New Haven, CT: Yale University Press.

Conrad C (1966; reprint 1990) The Theology of Jonathan Edwards: A Reappraisal. Garden City: Anchor Books; Bloomington, IN: Indiana University Press.

Lambert F (1999) Inventing the 'Great Awakening'. Princeton, NJ: Princeton University Press.

Marsden GM (2003) Jonathan Edwards, A Life. New Haven \& London: Yale University Press.

Morimoto A (2008) Jonathan Edwards and the Catholic Vision of Salvation. University Park, PA: The Pennsylvania State University Press.

Pfisterer KD (1975) The Prism of Scripture: Studies on History and Historicity in the Work of Jonathan Edwards. Frankfurt/M: Peter Lang.

Rudisill DP (1971) The Doctrine of the Atonement in Jonathan Edwards and his Successors. New York, NY: Poseidon Books, Inc. 
Story AF Jr (1994) Promoting Revival: Jonathan Edwards and Preparation for Revival. PhD Thesis, Westminster Theological Seminary.

[This article was published previously is Moga D (2008) The Theology of Revival in Jonathan Edwards. Oradea: Emanuel University Press, pp. 47-67.] 